\title{
Laporan Sumber Modal dan Penggunaan Modal Kerja Pada Perusahaan Handjaya Mandala Sampoerna Tbk Di Bursa Efek Indonesia (BEI)
}

\author{
Diana Fransiska ${ }^{1}$, M. Aryo Arifin ${ }^{2}$, Andri Eko Putra ${ }^{3}$ \\ ${ }^{1}$ Fakultas Ekonomi dan Bisnis Universitas PGRI Palembang, fransiskadiana51@gmail.com \\ ${ }^{2}$ Fakultas Ekonomi dan Bisnis Universitas PGRI Palembang, aryo.83arifin@gmail.com \\ ${ }^{3}$ Fakultas Ekonomi dan Bisnis Universitas PGRI Palembang, andri_ekoputra@yahoo.com
}

\begin{abstract}
The purpose of this study was to find out the report on sources of capital and the use of working capital at the Handjaya Mandala Sampoerna Tbk Company on the Indonesia Stock Exchange. PT Handjaya Mandala Sampoerna is one of the leading cigarette industries in the country which has been established since 1913 in the city of Surabaya, until now Handjaya Mandala Sampoerna has been widely known both domestically and abroad as a producer of high quality kretek cigarettes. Reports on sources of capital and use of working capital are used to find out the results of financial activities in the company in a certain period and to see the causes of changes in working capital and to find out reports on sources of capital and use of working capital. The research method used by the author is descriptive and quantitative methods. The data used is secondary data in the form of financial statements. The data collection technique used is the documentation technique. The results of this study indicate that the Handjaya Mandala Sampoerna Tbk Company on the Indonesia Stock Exchange in compiling the comparative balance sheet in 2016-2017 and 2018 the company always experiences an increase in working capital every year. This is due to an increase in assets that is greater than the increase in total current liabilities. And the report on changes in working capital has a fairly good working capital management because in 2016-2017 it experienced an increase of Rp. 632,786 and from 2017-2018 it can be seen that the management of working capital continues to result in an increase in working capital. While the results of the report on sources of capital and the use of working capital of Pt Handjaya Mandala Sampoerna Tbk have a good source of working capital because in 2016-2017 and 2018 the source of working capital is greater than the use of working capital.
\end{abstract}

Keyword: sources of capital, use of working capital.

\begin{abstract}
ABSTRAK
Tujuan penelitian ini untuk mengetahui Laporan Sumber Modal Dan Penggunaan Modal Kerja Pada Perusahaan Handjaya Mandala Sampoerna Tbk Di Bursa Efek Indonesia. PT Handjaya Mandala Sampoerna merupakan salah satu industri rokok termuka di tanah air yang telah berdiri sejak tahun 1913 di kota Surabaya, hingga kini Handjaya Mandala Sampoerna sudah terkenal luas baik di dalam negeri maupun mancanegara sebagai penghasil rokok kretek berkualitas tinggi. Laporan sumber modal dan penggunaan modal kerja digunakan untuk mengetahui hasil-hasil aktivitas keuangan pada perusahaan dalam suatu periode tertentu dan utuk melihat penyebab-penyebab terjadinya perubahan modal kerja serta untuk mengetahui laporan sumber modal dan penggunaan modal kerja. Metode penelitian yang digunakan penulis adalah motode Deskriftif dan Kuantitatif. Data yang digunakan yaitu data sekunder berupa laporan keuangan. Teknik pengumpulan data yang digunakan adalah teknik dokumentasi. Hasil penelitian ini menunjukan bahwa Perusahaan Handjaya Mandala Sampoerna Tbk Dibursa Efek Indonesia dalam menyusun neraca perbandingan pada tahun 2016-2017 dan 2018 perusahaan setiap tahunnya selalu mengalami peningkatan modal kerja. Hal ini disebabkan peningkatan aktiva yang lebih besar dibandingkan dengan peningkatan total kewajiban lancarnya. Dan laporan perubahan modal kerja memiliki pengelolaan modal kerja yang cukup baik karena ditahun 2016-2017 mengalami prningkatan Rp 632.786 dan dari tahun 2017-2018 terlihat pengelolaan modal kerjanya yang terus menghasilkan peningkatan modal kerja. Sedangkan hasil laporan sumber modal dan penggunaan modal kerja Pt Handjaya Mandala Sampoerna Tbk ini memiliki sumber modal kerja yang baik karena ditahun 2016-2017 dan 2018 sumber modal kerjanya lebih besar dari pada penggunaan modal kerja.
\end{abstract}

Kata Kunci : Sumber Modal, Penggunaan Modal Kerja 


\section{A. PENDAHULUAN}

Pengertian sumber modal kerja merupakan standar untuk menilai sumber modal kerja yang bisa dilihat di konsep modal kerja saat penjualan semakin meningkat dan melampaui batas biaya modal kerja yang dikeluarkan artinya perusahaan dapat memperoleh keuntungan (profit) dan begitu pula sebaliknya. (Irham fahmi, 2012 : 103)

Manajer perusahaan tidak terhindar dari masalah permodalan yaitu pemenuhan modal kerja maupun investasi. Sumber dan panggunaan modal kerja ialah analisa yang bisa dijadikan gambaran untuk mengambil kesimpulan yang tepat, artinya dengan analisa sumber dan penggunaan modal kerja pemimpin dapat melihat stuktur modal kerja bersumber dari mana dan digunakan untuk apa, sehingga pemimpin dapat mengarahkan modal kerja itu sendiri.

Laporan sumber dan modal kerja ini akan membantu manajer kauangan untuk menjalankan operasional perusahaan dalam menentukan jumlah dana yang harus tersedia dan untuk melihat asal sumber dana itu didapat. Selain itu, laporan tersebut dapat juga membantu manajer keuangan dalam menyusun berapa penggunaan dana dengan sebaik-baiknya. Untuk dapat mencegah hal-hal yang tidak di inginkan diperusahaaan tersebut karena apabila perusahaan kekurangan dana tentu akan sulit berkembang, kekurangan modal kerja jika terus menerus tidak segera diatasi tentu akan menghambat perusahaan dalam mencapai tujuannnya.

Peranan modal kerja sangat penting dalam perusaahaan bisa dikatakan sebagai nyawa dari sebuah perusahaan artinya untuk menjalaankan kegiatan operasionalnya sehari-hari ataupun untuk mengadakan investasi dibutuhkan modal kerja yang cukup untuk memperoleh modal kerja, pihak perusahaan harus memperhatikan setiap kemampuan keuangan yang ada dan yang bisa digunakan dengan memperhatikan segala kemungkinan resiko yang ditimbulkan.

Modal kerja yang berlebihan menunjukkan adanya dana yang tidak produktif yang dalam hal ini menimbulkan kerugian bagi perusahaan, karena dengan adanya kesempatan untuk memperoleh keuntungan telah disia-siakan sebaliknya, dengan adanya ketidak cukupan kerja sangatlah mempengaruhi kegiatan perusahaan tidak dapat berjalan sebagimana mestinya.

Analisa sumber dan penggunaan modal kerja sangatlah penting bagi perusahaan karena informasi modal kerja untuk menilai apakah perusahaan telah menggunakan modal kerja dengan baik dan apakah laba yang didapat sesuai dengan biaya yang dikeluarkan.

Untuk dapat menghindari bahaya adanya krisis keuangan ataupun kebuutuhan dana, perusahaan perlu menata penggunaan modalnya dengan seefisien mungkin sehingga tercipta kesesuaian kebutuhan dana yang tersedia.

Sumber dan penggunaan modal kerja ini dapat dilihat dari laporan posisi keungan laporan laba rugi komprehensif dari perusahaan, dengan mendeteksi secara jelas perubahan yang terjadi dari neraca dan laporan perhitungan dari laba rugi, maka diharapkan pemilik dan manajer perusahaan mengetahui secara nyata perubahan dari setiap periode ke periode apakah perusahaan mengalami keuntungan atau kerugian dan juga dapat mengetahui laba rugi yang dialami oleh perusahaan.

Jadi modal kerja suatu perusahaan merupakan peran yang sangat penting yang tidak pernah terlepas dari suatu perusahaan, dan sudah jelas bahwa perusahaan harus dapat melaksanakan pengaturan modal kerja sebaik-baiknya sehingga 
perusahaan dapat mencapai keuntungan yang wajar. Hal ini bearti bahwa dana yang tersedia tidak mengalami kekurangan atau kelebihan.

\section{B. KAJIAN TEORI}

\section{Pengertian Modal Kerja}

Menurut kasmir (2014:248) analisis sumber dan penggunaan modal kerja merupakan analisis yang berhubungan dengan sumber sumber dana dan penggunaan dana yang berkaitan dengan modal kerja perusahaan Artinya dari mana saja perusahaan memperoleh dana guna membiayai kegiatan Kemudian dana yang sudah diperoleh tersebut digunakan untuk aktivitas apa saja.

Harmono (2017:193) menyatakan modal kerja adalah aktiva lancar, Modal kerja dapat diartikan sebagai pengelolaan terhadap komponen-komponen aktiva lancar. Dalam konteks ini antara komponen kas dengan komponen aktiva lancar piutang dan persediaan seling terkait dan membutuhkan pengelolaan yang memadai sesuai fluktuasi kebutuhan modal kerja perusahaan.

Lukman Syamsuddin (2013:201) menyatakan modal kerja ialah salah satu aspek terpenting dari keseluruhan manajemen pembelanjaan perusahaan Jika perusahaan tidak dapat mempertahankan tingkat modal kerja yang memuaskan maka perusahaan akan berada dalam keadaan insolvent tidak bisa membayar beban beban yang sudah jatuh tempo dan mungkin harus terpaksa dilikuidir bangkrut

Menurut irham fahmi (2013:102), setiap perusahaan membutuhkan modal kerja untuk membiayai operasi sehari-hari misalnya untuk membeli bahan mentah,gaji pegawai, upah dan lain-lain sebagainya. Pada intinya setiap perusahaan akan selalu membutuhkan modal kerja dalam menjalankan kegiatan seluruh operasional didalam perusahaan tersebut.

Adanya modal kerja yang cukup sangat penting bagi suatu perusahaan, karena dengan modal kerja yang cukup itu memungkinkan bagi perusahaan untuk beroperasi dengan seekonomis mungkin dan perusahaan tidak mengalami kesulitan atau menghadapi bahaya-bahaya yang mungkin timbul karena adanya krisis atau kekacauan keuangan.

Irham Fahmi (2013:105) juga menyatakan pengertian modal kerja terbagi menjadi duaa macam, yaitu:

1. Konsep Kuantitatif, menyebutkan bahwa modal kerja adalah seluruh asett lancar. Konsep ini yang perlu mendapat perhatian adalah bagaimana mencukupi kebutuhan dana untuk membiayai operasi perusahaan dalam jangka pendek.konsep ini sering disebut dengan modal kerja kotor (gross working capital)

2. Konsep Kualitatif

Merupakan konsep yang menitikberatkan kepada kualitas modal kerja. Konsep ini melihat selisih antara aset lancar dengan kewajiban lancar. Konsep ini disebut modal kerja bersih atau (net working capital).

3. Konsep Fungsional

Menekankan kepada fungsi dana yang dimiliki perusahaan dalam memperoleh laba. Artinya sejumlah dana yang dimiliki dan digunakan perusahaan untuk meningkatkan laba perusahaan.

Modal kerja memiliki arti yang sangat penting bagi operasional suatu perusahaan. Disamping itu, manajemen modal kerja juga memiliki tujuan tertentu yang hendak dicapai oleh karena itu, setiap perusahaan berusaha memenuhi 
kebutuhan modal kerjanya, agar dapat meningkatkan likuiditasnya. Kemudian, dengan terpenuhi modal kerja, perusahaan juga dapat memaksimalkan perolehan labanya, perusahaan dalam kekurangan modal kerja dapat membahayakan kelangsungan hidup perusahaan yang bersangkutan karena sulit atau tidak dapat memenuhi likuiditas dan target laba yang diinginkan (Kasmir, 2014:252)

Kasmir (2014:252) Dalam bukunya menyatakan arti penting modal kerja bagi perusahaan, terutama bagi kesehatan keuangan dan kinerja perusahaan yaitu sebagai berikut:

1. Kegiatan seorang manajer keuangan lebih banyak dihabiskan di dalam kegiatan operasional perusahaan dari waktu ke waktu, ini merupakan manajemen modal kerja.

2. Investasi dalam aktiva lancar cepat sekali berubah dan sering kali mengalami perubahan dan cenderung labil. Perubahan tersebut akan mempengaruh terhadap modal kerja perusahaan. Oleh karena itu,perlu manajemen modal mendapat perhatian yang sunggh-sungguh dari manajer keuangan.

3. Sering kali mengalami perubahan secara cendrung labil. Perubahan tersebut akan berpengaruh terhadap modal kerja oleh karena itu perlu mendapat perhatian yang sungguh-sungguh dari manajer kauangan.

4. Dalam praktiknya sering kali bahwa lebih dari separuh dari total aktiva merupakan bagian dari aktiva lancar, yang merupakan modal kerja perusahaan. Artinya jumlah aktiva lancar sama atau lebih dari 50\% dari total aktiva, dengan kata lain lebih dari separuh jumlah aktiva di investasikan dalam aktiva lancar.

5. Khusus bagi perusahaan kecil manajemen modal kerja sangat penting karena investasi dalam aktiva tetap dapat ditekan dengan menyewa, tetapi investasi lancar dalam piutang dan sediaan tidak dapat dihindarkan harus segera dipenuhi.

6. Bagi perusahaan yang relatif kecil fungsi ,odal kerja juga amat peting. Hal ini disebabkan perusahaan kecil, relativf terbatas untuk memasuki pasar dengan modal besar dan jangka panjang, pendanaan perusahaan lebih mengandalkan pada utang jangka pendek, seperti utang dagang, utang bank 1 tahun yang tentunya dapat mempengaruhi modal kerja.

7. Terdapat hubungan sangat erat antara pertumbuhan penjualan dengan kebutuhan modal kerja. Kenaikan penjualan berkaitan dengan tambahan piutang, sediaan dan juga saldo kas. Demikian pula sebaliknya, apabila terjadi penurunanpenjualan, akan berpengaruh terhadap komponen dalam aktiva lancar.

Tujuan manajemen modal kerja pada perusahaan sebagai berikut Kasmir (2014:253) :

a. Modal kerja digunakan untuk memenuhi kebutuhan likuiditas perusahaan, artinya likuiditas suatu perusahaan sangat tergantung kepada manajemen modal kerja.

b. Dengan modal kerja yang cukup perusahaan memiliki kemampuan untuk memenuhi kewajiban pada waktunya. Pemenuhan kewajiban yang sudah Jatuh tempo dan segera harus dibayar secara tepat waktu merupakan ukuran keberhasilan manajemen modal kerja.

c. Memungkinkan perusahaan untuk memiliki sediaan yang cukup dalam rangka memenuhi kebutuhan pelanggannya. 
d. Memungkinkan perusahaan untuk memperoleh tambahan dana dari para kreditor, apabila resiko keuangannya memenuhi syarat seperti likuiditas yang terjamin.

e. Memungkinkan perusahaan memberikan syarat kredit yang menrik minat pelanggan,dengan kemampuan yang dimilikinya.

f. Guna memaksimalkan penggunaan aktiva lancar guna meningkatkan penjualan laba.

g. Perusahaan mampu melindungi diri apabila terjadi krisis modal kerja akibat turunnya nilai aktiva lancar.

Menurut kasmir (2014:212) menyatakan bahwa manajemen modal kerja artinya kegiatan yang berhubungan pengelolaan modal kerja secara keseluruhan seperti yang telah dijelaskan diatas, kegiatan yang berhubungan dengan sumber-sumber dana dan penggunaan yang berkaitan dengan modal kerja perusahaan dalam arti luas bisat dikatakan dari mana saja perusahaan memperoleh dana guna membiayai kegiatannya dan digunakan untuk aktivitas apa saja dana yang sudah diperoleh tersebut.

Manajemen modal kerja pada perusahaan sangatlah penting guna mendukung pencapaian tujuan perusahaan. Dalam praktiknya terdapat nilai penting manajemen modal kerja dikarenakan :

$>$ Jumlah aktiva lancar dalam perusahaan biasanya jumlahnya lebih dari separuh total aktiva yang dimilikinya (khususnya perusahaan manufaktur) dan jumlah ini akan lebih besar lagi bagi perusahaan yang bergerak dalam bidang distribusi.

$>$ Jumlah kas yang sangat dibutuhkan untuk memenuhi berbagai pembayaran perusahaan terutama yang sudah jatuh tempo atau pembelian kebutuhan lainnya seperti bahan baku.

$>$ Perlu perencanaan matang dan pengawasan terus-menerus bagi piutang jangan sampai mengganggu modal kerja karena terjadi kemacetan pembayaran.

> Jumlah sediaan yang ada jangan sampai terjadi kekurangan atau kelebihan karena komponen ini sangat rentan bagi kelangsungan hidup perusahaan.

$>$ Apabila suatu aktiva lancar tidak di-menege secara baik, maka dapat berakibat pada realisasi pengambilan investasi yang dibawah standar.

Maka dari itu dapat dikatakan bahwa manajemen modal kerja merupakan penentu yang amat penting bagi perusahaan:

a. Optimasi dari investasi pada asset lancar

b. Kombinasi antara pembiayaan jangka pendek yang digunakan untuk mendukung investasi pada asset lancar.

Menurut Irham Fahmi (2013:115) fungsi modal kerja yaitu antara lain :

1. Melindungi perusahaan terhadap krisis moda kerja turunnya nilai asset lancar.

2. Memungkinkan untuk dapat membayar semua kewajiban-kewajiban tepat pada waktunya.

3. Menjamin dimilikinya kredit standing perusahaan semakin besar dan memungkinkan bagi perusahaan untuk menghadapi bahaya-bahaya atau kesulitan keuangan yang mungkin terjadi.

4. Memungkinkan untuk memiliki persediaan dalam jumlah yang cukup untuk melayani para konsumen. 
5. Memungkinkan bagi perusahaan untuk memberikan syarat kredit yang lebih menguntungkan kepada para langganan.

6. Memungkinkan bagi perusahaan untuk dapat beroperasi dengan lebih efisien karena tidak kesulitan untuk memperoleh barang ataupun jasa yang dibutuhkan.

Jenis-jenis modal kerja yang dimiliki perusahaan terbagi menjadi dua yaitu Irham Fahmi (2013:106) :

1. Modal Kerja Kotor ( gross working capital)

lalah semua faktor yang ada diaktiva lancar secara keseluruhan dan yang disebut modal kerja. Artinya mulai dari kas perusahaan, surat berharga, piutang, persediaan dan akiva lancar lainnya.

2. Modal Kerja Bersih ( net working capital)

lalah merupakan semua faktor aktiva lancar yang dikurangi dengan seluruh total kewajiban lancar utang jangka pendek. Artinya utang lancar meliputi utang dagang, utang wesel, utang bank jangka pendek 1 tahun, utang gaji, utang pajak dan utang lancar lainnya.

Setiap perusahaan yang telah melakukan kegiatan maka kebutuhan modal kerjanya akan terlihat jelas sekali. Modal kerja bisa digambarkan sebagai pengeluaran yang bukan harga tetap baik langsung maupun tidak langsung yang dilakukan oleh perusahaan. Jadi dapat disimpulkan modal kerja merupakan hasil yang terus-menerus yang memperantarai antara saat pengeluaran uang yang menjalankan operasional perusahaan sampai dengan penerimaan hasil usaha perusahaan.

Modal kerja ialah ketersediaan modal kerja yang dibutuhkan perusahan harus segera terpenuhi sesuai kebutuhan perusahaan. Namun untuk terpenuhi modal kerja perusahaan sangat tidak mudah hal ini disebabkan kebutuhan modal kerja sangat bergantung pada berbagai faktor yang mempengaruhinya. Maka dari itu pihak manajemen untuk menjalankan kegiatan operasional perusahaan dalam upaya pemenuhan modal kerja harus selalu memperhatikan faktor-faktor tersebut.

Dari penjelasan diatas ada beberapa faktor yang dapat mempengaruhi modal kerja dalam perusahaan, antara lain sebagai berikut Kasmir (2014:254):

1. Jenis perusahaan

Yaitu perusahaan yang bergerak dalam bidang jasa dan nonjasa dan bisa disebut industri. Kepentingan modal kerja di perusaahaan lebih besar jika dibandingkan dengan perusahaan jasa. Perusahaan industri, investasi dalam bidang kas, piutang, dan kesediaan relative besar dibandingkan diperusahaan jasa. Maka dari itu operasional perusahaan sangat menentukan kebutuhan modal kerjanya.

2. Syarat kredit

Syarat kredit atau penjualan yang pembayarannya yang dilakukan dengan cara mecicil (angsuran) ini juga sangat mempengaruhi modal kerja. Dan untuk meluaskan penjualan biasa dilakukan dengan berbagai cara yang salah satunya yaitu melalui penjualan secara kredit untuk kelonggaran kepada konsumen yang akan membeli barang dalam jangka waktu yang tertentu. Halhal yang perlu memperoleh perhatian dari syarat-syarat kredit terbagi menjadi dua bagian yaitu:

$>$ Syarat untuk pembelian bahan atau barang dagangan 
Syarat pembelian bahan atau barang dagang yang akan digunakan untuk memproduksi barang mempengaruhi modal kerja. Pengaruhnya berdampak pada pengeluaran kas, apabila persyaratan kredit lebih mudah maka akan sedikit uang kas yang terkeluar begitu pula sebaliknya, syarat untuk pembelian bahan atau barang dagang juga memiliki kaitannya dengan sediaan.

$>$ Syarat penjualan barang

Syarat penjualan barang ialah, apabila sayart kredit diberikan relative lunak seperti potongan harga. Maka modal kerja yang dibutuhkan makin besar modal yang dibutuhkan dalam sektor piutang. Tetapi agar modal kerja yang diinvestasikan dalam sektor piutang dapat diperkecil maka perusahaan perlu memberikan potongan harga yang bertujuan untuk menarik minat para debitur untuk segera membayar utangnya, dan juga dapat memperkecil kemungkinan resiko utang tak tertagih.

3. Waktu produksi

Waktu produksi artinya jangka waktu atau lamanya membuat suatu barang. Maka makin lama waktu untuk memproduksi suatu barang dan akan makin besar modal kerja yang dibutuhkan demikian pula sebaliknya makin sedikit waktu yang dibutuhkan untuk memproduksi modal kerja, maka makin kecil modal kerja yang dibutuhkan.

4. Tingkat perputaran sediaan

Akibat tingkat perputaran persediaan modal kerja cukup penting bagi perushaan, semakin kecil atau rendah tingkat perputaran maka kebutuhan modal kerja makin tinggi, begitu pula sebaliknya dengan demikian dibutuhkan perputaran persediaan yang cukup tinggi untuk memperkecil resiko kerugian pada perusahaan akibat penurunan harga yang mampu menghemat biaya penyimpanan dan pemeliharaan sediaan.

Maka dari itu kenaikan dan penurunan modal kerja diesebabkan tiga faktor, yaitu:

1. Adanya kenaikan modal. Artinya adanya tambahan modal dari pemilik atau perolehan laba dalam periode tertentu yang dimaksudkan ke aktiva lancar.

2. Adanya pengurangan aktiva tetap. Artinya adanya penjualan aktiva tetap terutama yang tidak produktif dimana uangnya dimasukan ke aktiva lancar atau digunakan untuk membayar utang jangka pendek.

3. Adanya penambahan utang. Artinya perusahaan menambah utang baru dalam jangk pendek maupun panjang.

Ada beberapa sumber modal kerja yang dapat diperoleh dari penurunan jumlah asset dan kenaikan kewajiban (hutang) sebagai berikut:

1. Hasil Operasi Perusahaan

Hasil operasi perusahaan artinya pendapatan atau laba yang diperoleh pada periode tertentu dan ditambah dengan penyusutan misalnya cadangan laba, atau laba yang belum dibagi. Saat laba yang belum dibagi oleh perusahaan tidak diambil pemegang saham, maka akan menambah modal kerja perusahaan, tetapi modal kerja ini sifatmya hanya sementara waktu saja dalam waktu relatif tidak terlalu lama.

2. Keuntungan Penjualan Surat Berharga

Keuntungan surat berharga ialah bisa digunakan untuk keperluan modal kerja. Banyaknya selisih dengan harga beli dan harga jual surat berharga tersebut, 
tetapi sebaliknya apabila terpaksa harus menjual surat berharga dalam keadaan rugi maka otomatis dapat mengurangi modal kerja.

3. Penjualan Saham

Penjualan saham artinya perusahaan melepas sejumlah saham yang masih dimiliki untuk dijual kepada berbagai pihak, maka hasil saham ini dapat digunakan sebagai modal kerja.

4. Penjualan Obligasi

Penjualan obligasi adalah artinya perusahaan mengeluarkan sejumlah obligasi untuk dijual kepada pihak lainnya. Dan dari hasil penjualan ini dapat dijadikan modal kerja sekalipun hasil penjualan obligasi lebih diutamakan kepada pemegang saham perusahaan dalam waktu jangka panjang.

5. Penjualan Aktiva Tetap

Pada penjualan aktiva tetap. Maksudnya yang dijual adalah aktiva tetap yang kurang produktif atau masih menganggur.

6. Memperoleh Pinjaman

Mengenai memperoleh pinjaman dari kreditor (bank atau lembaga lain), terutama pinjaman jangka pendek, khusus untuk pinjaman jangka panjang dapat digunakan, hanya saja peruntukan pinjaman jangka panjang biasanya digunakan untuk kepentingan investasi.

\section{Penggunaan Modal Kerja}

Setelah memperoleh modal kerja yang diinginkan, tugas manajer keuangan adalah menggunakan modal kerja tersebut. Hubungan antara sumber dan penggunaan modal kerja sangat erat. Artinya penggunaan modal dipilih dari sumber modal kerja tertentu atau sebaliknya. Penggunaan modal kerja akan dapat mempengaruhi jumlah modal kerja itu sendiri. Seorang manajer dituntut untuk menggunakan modal kerja secara tepat, sesuai dengan sasaran yang ingin dicapaai perusahaan. diambil untuk mengatasinya.

Kasmir (2010:222) menyatakan penggunaan dana dan untuk modal kerja dapat dilihat dari kenaikan aktiva dan menurunnya pasiva, berikut ada beberapa penggunaan modal kerja bisa dilakukan perusahaan untuk tujuan:

1. Pengeluaran untuk gaji, upah dan biaya operasional lainnya. Artinya perusahaan mengeluarkan sejumlah uang atau membayar gaji, upah dan biaya operasi lainnya yang digunakan untuk penunjang penjualan.

2. Pengeluaran untuk membeli bahan baku atau barang dagangan. Artinya ada sejumlah bahan baku yang dibeli yang akan digunakan untuk proses produksi dan pembelian barang dagangan yang digunakan untuk dijual kembali

3. Menutupi kerugian akibat penjualan surat berharga. Artinya pada saat perusahaan menjual surat berharga namun mengalami kerugian dan ini akan mengurangi modal kerja dan segera ditutupi.

4. Pembentukan dana 14 merupakan pemisahan aktiva lancar untuk tujuan tertentu dalam jangka panjang.

5. Pembelian aktiva tetap (tanah,bangunan,kendaraan,mesin dan lainlain).pembelian ini akan mengakibatkan berkurangnya aktiva lancar dan timbulnya utang lancar.

6. Pembayaran utang jangka panjang. Artinya adanya pembayaran utang jangka yang tempo. 
7. Pembelian atau penarikan kembali saham yang beredar. Artinya perusahaan menarik kembali saham-saham yang sudah beredar dengan alasan tertentu dengan cara membeli baik untuk sementara waktu maupun selamanya.

8. Pengambilan utang atau barang untuk kepentingan pribadi. Artinya pemilik perusahaan mengambil barang atau dagang yang digunakan untuk kepentingan pribadi.

Laporan sumber dan penggunaan modal kerja menunjukan bagaimana perputaran modal kerja selama periode tertentu, laporan sumber dan penggunaan modal kerja juga menunjukkan kinerja manajemen dalam mengelola modal kerjanya maka akan terlihat perubahan modal kerja yang dimiliki perusahaan, laporan modal kerja biasa disebut dengan statement of fund atau statement of financial changers

Dari uraian diatas dapat disimpulkan laporan perubahan modal kerja ialah ringkasan mengenai hasil-hasil aktivitas keuangan suatu perusahaan dalam setiap periode dan menyajikan sebab-sebab perubahan posisi keuangan tersebut. Laporan ini sangat berguna bagi manajemen untuk mengadakan pengawasan terhadap modal kerja di suatu perusahaan.

\section{METODE PENELITIAN}

1. Populasi dan Sampel

Sugiyono (2014:115) populasi diartikan sebagai wilayah generalisasi sebuah objek atau subjek yang memiliki kualitas dan karakteristik tertentu yang ditetapkan oleh peneliti dalam mempelajari dan ditarik kesimpulanya, populasi yang digunakan penelitian ini yaitu data laporan keuangan pada Pt Handjaya Mandala Sampoerna Tbk di Bursa Efek Indonesia (BEI).

Sugiyono (2014:116) sampel merupakan bagian dari jumlah dan karakteristik yang dimilliki oleh populasi tersebut. Adapun sampel yang diambil dari peneltian ini laporan keuangan Pt Handjaya Mandala Sampoerna pada tahun 2016 - 2018.

\section{Sumber Data}

Dalam penelitian ini sumber data yang digunakan yaitu data sekunder. Sumber data dalam penelitian ini diperoleh dari Galeri Investasi Bursa Efek Indonesia yang beralokasi di Unika Musi Charitas Palembang.

\section{Metode pengumpulan Data}

Metode pengumpulan data dalam penelitian ini adalah:

a. Data sekunder merupakan data yang didapat secara tidak langsung dari perusahaan berupa laporan keuangan yang bersumber di Bursa Efek Indonesia.

b. Dokumentasi yaitu mengumpulkan, mencatat dan mengelola data sekunder yang berupa laporan keuangan tahunan di perusahaan Handjaya Mandala Sampoerna yang terdaftar Bursa Efek Indonesia.

\section{Teknik Analisis Data}

Sugiyono (2014:428) analisis data merupakan proses pencarian dan menyusun secara sistematis data yang diperoleh dari hasil dokumentasi dan penelitiankeperpustakaan. Untuk menganalisis permasalahan yang akan dibahas dalam penulisan ini, penulis akan menganalisis laporan keuangan yang telah dipublikasikan oleh Bursa Efek Indonesia (BEI). 


\section{HASIL DAN PEMBAHASAN}

Ikhtisar Neraca Perbandingan Perusahaan Handjaya Mandala Sampoerna Tbk di BEl (Dalam Jutaan Rupiah)

\begin{tabular}{|c|c|c|c|}
\hline \multicolumn{1}{|c|}{ Perusahaan } & $\mathbf{2 0 1 6}$ & $\mathbf{2 0 1 7}$ & $\mathbf{2 0 1 8}$ \\
\hline $\begin{array}{l}\text { Perusahaan Handjaya } \\
\text { Mandala Sampoerna Tbk }\end{array}$ & 42.508 .277 & 43.141 .063 & 46.602 .420 \\
\hline
\end{tabular}

Berdasarkan tabel di atas terlihat bahwa PT. Handjaya Mandala Sampoerna Tbk memiliki pengelolaan modal kerja yang baik kerena di tahun 2016-2017 dan 2018 terlihat jumlah peningkatan modal kerja perusahaan setiap tahunnya selalu mengalami peningkatan, modal kerjanya sangat tinggi hampir mencapai $100 \%$ dari total modal kerja. Hal ini disebabkan dalam mengelola modal kerjanya baik dari sisi pemilihan sumber modal kerja maupun penggunaan sumber modal kerja tersebut perusahaan memprioritaskan sumber dan penggunaan modal kerja yang dapat mendatangkan keuntungan dimasa yang akan mendatang.

Berdasarkan laporan perubahan modal kerja pada tahun 2016 modal kerja perusahaan yaitu sebesar Rp 42.508 .277 sedangkan pada tahun 2017 modal kerja perusahaanyaitu sebesar $\mathrm{Rp} 43.141 .063$ dan pada tahun 2017 perusahaan ini mengalami peningkatan yaitu $\mathrm{Rp} 632.786$. hal ini disebabkan terjadinya peningkatan aktiva yaitu sebesar Rp 632.786.

Dan pada tahun 2017 jumlah modal kerja perusahaan yaitu sebesar Rp 43.141.063 dan sedangkan pada tahun 2018 jumlah modal kerja perusahaan yaitu sebesar Rp 602.420. pada tahun 2018 perusahaan ini mengalami penurunan yaitu sebesar Rp 42.538.643 hal ini disebabkan terjadinya penurunan aktiva yaitu sebesar Rp 42.538.643.

Berdasarkan laporan sumber dan penggunaan modal kerja Pt Handjaya Mandala Sampoerna Tbk dari tahun ketahun sumber modal kerjanya terutama berasal dari sumber internal perusahaan yaitu dari laba operasi, bertambahnya aktiva tetap, bertambahnya hutang jangka panjang, berkurangnya modal. Sehingga dengan peningkatan sumber modal kerja tersebut dapat menunjang kelancaran operasional perusahaan tanpa menimbulkan kewajiban membayar kembali dana yang dipakai dikemudian hari. Begitu pula penggunaan modal kerjanya setiap tahunnya diutamakan utnuk pos-pos yang dapat mendatangjan keuntungan dimasa yang akan datang seperti berkurangnya aktiva tetap dan pembayaran deviden.

Dan berdasarkan analisis di atas terlihat bahwa sumber dan penggunaan modal kerja Pt Handjaya Mandala Sampoerna Tbk telah memenuhi kriteria sumber modal kerja yang baik karena lebih mengutamkan sumber internal dalam pemilihan sumber modal kerjanya. Dimana sumber internal diketahui tidak akan menmbulkan kewajiban membayar dana yang dipakai dimasa yang akan datang.

Berdasarkan pada neraca perbandingan laporan sumber dan penggunaan modal kerja maka dapat dilihat setiap perubahan pada akun-akunnya dari tahun 2016 adanya kenaikan aktiva lancar yaitu sebesar $\mathrm{Rp} 42.508 .277$ dan pada kewajibannya yaitu sebesar Rp 8.333.263, pada tahun 2017 adanya kenaikan aktiva lancar terjadi pada akun-akunya yaitu sebesar $\mathrm{Rp} 43.141 .063$ dan pada kewajibannya yaitu sebesar Rp 9.028.078

Sedangkan pada tahun 2018 adanya kenaikan aktiva lancar terjadi pad akunakunnya yaitu sebesar Rp 46.602.420 dan pada kewajibannya yaitu sebesar Rp 8.333.263. dari hasil analisis maka dapat diketahui bahwa Modal Kerja mengalami 
kenaikan karena jumlah aktiva lancar lebih besar dibandingkan dengan kewajiban lancar.

\section{E. KESIMPULAN DAN SARAN}

1. Kesimpulan

Berdasarkan analisis laporan sumber dan penggunaan modal kerja pada perusahaan Handjaya Mandala Semporna Tbk ini menunjukan pengelolaan modal kerja yang baik. Karena baik dalam hal pemilihan sumber dan penggunaan modal kerjanya perusahaan ini sangat memperhatikan semua aspek-aspek yang dapat memaksimalkan nilai perussahaan yaitu mendatangkan keuntungan bagi perusahaan di masa yang akan datang, dan dapat mempertahankan suatu kondisi sumber modal kerja lebih besar dari penggunaan modal kerja sehingga perusahaan mengalami kenaikan modal kerja, ini bearti akan diperoleh modal kerja yang cukup sehingga menunjang kelancaran operasional perusahaan.

\section{Saran}

Perusahaan Handjaya Mandala Sampoerna Tbk telah memiliki pengelolaan modal kerja yang baik, hal ini sebenarnya sangat menguntungkan bagi perusahaan maka sebaiknya modal kerja ini dapat digunakan seoptimal mungkin dalam mendukung kegiatan agar terus dipertahankan, ditingkatkan dan terus dapat mempertahankan eksistensi usahanya kedepan meningkat ketatnya persaingan usaha saat ini.

Untuk meningkatkan kepercayaan pengelolaan modal kerja yang baik terhadap perusahaan, maka perusahaan harus menunjukan kinerja perusahaan yang baik serta menyempaikan informasi yang cukup mengenai perkembangan perusahaaan.

\section{DAFTAR PUSTAKA}

Bursa Efek Indonesia. (2020). https://www.idx.co.id

Fahmi, Irham. (2013). Pengantar Manajemen Keuangan. Alfabeta : Bandung

Harmono. (2017). Manajemen Keuangan. Aksara : Jakarta

Kasmir. (2014). Pengantar Manajemen Keuangan. Kencana : Jakarta

Lubis, Abdul. Rahman (2017). Analisis Sumber dan Penggunaan Modal Kerja Dalam Meningkatkan Likuiditas Perusahaan Pada PT Siantar Top Tbk.

Maswatu, A. Ghazali; Pelleng, Frendy; Tampi, Dolina. Analisis Sumber dan Penggunaan Modal Kerja Pada PT Bank Tabungan Negara (Persero) Tbk. Cab. Manado. Jurnal Administrasi Bisnis, 2016, 4.2.

Sugiyono. (2014). Metode Penelitian Bisnis. Alfabeta : Bandung

Syamsuddin Lukman. (2013). Manajemen Keuangan Perusahaan. Jakarta

Suratinoyo, A. (2016). Analisa Laporan Sumber-Sumber dan Penggunaan Modal Kerja Dalam Meningkatkan Profitabilitas Perusahaan Pada PT Fast Food. Tbk. Jurnal Berkala Ilmiah Efisiensi, 16(3). 